\title{
XXIV. On the geology and palœontology of North America, in abstracts of a series of papers recently communicated to the Geological Society of London
}

\author{
David Dale Owen M.D. , Charles Lyell Esq. V.P.G.S. F.R.S. , Gideon Algernon
} Mantell LL.D. F.R.S. , W.C. Redfield Esq. \& J. Hamilton Cooper Esq.

To cite this article: David Dale Owen M.D. , Charles Lyell Esq. V.P.G.S. F.R.S. , Gideon Algernon Mantell LL.D. F.R.S. , W.C. Redfield Esq. \& J. Hamilton Cooper Esq. (1843) XXIV. On the geology and palœontology of North America, in abstracts of a series of papers recently communicated to the Geological Society of London, Philosophical Magazine Series 3, 23:151, 180-193, DOI: $10.1080 / 14786444308644715$

To link to this article: http://dx.doi.org/10.1080/14786444308644715

曲 Published online: 30 Apr 2009.

Submit your article to this journal $₫$

山 Article views: 3

View related articles 
XXIV. On the Geology and Palcontology of North America, in abstracts of a series of papers recently communicated to the Geological Society of London. By David Dale Owen, M.D.; Charles Lyeld, Esq., V.P.G.S., F.R.S.; Gideon Algernon Mantell, LL.D., F.R.S.; W. C. Redfiedid, Esq.; and J. Hamilton Cooper, Esq.

1. On the Geology of the Western States of North America. By David Dale Owen, M.D., of Indiana*.

THE remarks of the author relate chiefly to that part of the western states watered by the rivers Ohio, Wabash, Illinois, Rock, Wisconsin, Cumberland, and 'Tennessee, lying between $35^{\circ}$ and $43^{\circ}$ of north latitude, and $81^{\circ}$ and $91^{\circ}$ of west longitude. It includes the States of Illinois, Indiana, Ohio, Kentucky, Tennessee, and the Dubuque and Mineral Point districts of the territories of Jowa and Wisconsin. The observations recorded are the results of numerous excursions in those provinces, commenced in the year 1834, and continued to the present time by Dr. Owen, sometimes alone, at others accompanied by Dr. Troost and Dr. Locke, the state geologists respectively of Tennessee and Ohio. Though the territory under consideration occupies an area of about half a million of square miles, its geological features are remarkably uniform. With a few partial exceptions its formations belong to the eras of the bituminous coal, the mountain limestone of Europe, and the Silurian rocks of Murchison. The exceptions are the superficial deposits which occasionally cover these up from view, over considerable districts, and which themselves must be referred to the age of the gigantic mammalia and formations of a still more recent date; together with a marl and greensand in the western district of Tennessee, corresponding probably to the greensand and other members of the cretaceous group.

Of the tract described, the formations west of the Tennessee river occupy but a small corner, and the author has had but limited opportunities of examining them in person. The upper part of this group is an argillaceous marl of a light gray colour; the lower (of unascertained thickness) a greenish sandy marl. In no instance, as far as known to the author, has either the greensand or marl been discovered east of the Tennessee river. But it exists, according to Dr. Truost, under the superficial soil in most of the countries west of that river, extending probably west and south, into the states of Mississippi and Alabama. Both the marl and greensand are rich in fossils. In the former the most characteristic shell is the Exogyra. 'Though it is evident, from the character of the fossils imbedded in the marl and greensand beds, that these belong to the cretaceous group, yet hitherto no true chalk has been discovered in Tennessee, nor, so far as I know, in any of the United States.

In the territory described are two coal-fields of great extent. On the west is the great Illinois coal-field, equalling in area the entire island of Great Britain, occupying the greater part of Illinois, about one-third of Indiana, a north-western strip of Kentucky, and extend-

* Read before the Geological Society, Nov. 2, 1842. 


\section{Dr. D. Dale Owen on the Geology of North America. 181}

ing a short distance into Jowa. It is covered on the north by extensive diluvial deposits, sometimes to the depth of more than a hundred feet. The other coal-field forms a part of at least six states, viz. Ohio, Kentucky, Tennessee, Pennsylvania, Maryland, and Alabama; and its area is estimated at 50,000 square miles. These coal formations consist, as in Europe, of sandstones, shale, slaty clays, seams of coal, and occasionally beds of limestone, these latter usually dark-coloured and bituminous. At the base of the Ohio formation is a conglomerate from 200 to 300 feet in thickness, which has been referred to the millstone grit of England. A similar conglomerate shows itself in one or two localities at the base of the Illinois coal-field.

The thickness of these coal-fields is estimated at from 1200 to 2000 feet. All the coal is of a bituminous character, some of the caking variety, some splint coal, some cannel. Neither of the coalfields have suffered much from dislocation; no dykes of trap, whinstone, basalt, or greenstone have been met with in either. On the eastern flank, however, of the Cumberland mountains, the coal is occasionally much disturbed, even thrown up nearly vertically. There is a striking analogy between the fossil flora of these western coalfields and that of the equivalent strata in Europe. The most productive brines discovered in the western states have benn procured by boring through the lower members of the coal measures. Immediately below the coal-formations of Indiana, Ilinois, Kentucky, and Tennessee, are limestones mostly of a light gray colour and of a compact texture, including occasionally layers and nodules of chert. Some of these limestones assume the appearance of lithographic stone, others present a beautiful colitic structure. The strata vary in thickness; in Ohio it does not appear to exist, being replaced by the before-mentioned conglomerate. The great mammoth cave of Kentucky is in the upper beds of this limestone, which abound in subterraneous passages. These beds are characterized by two remarkable fossils, the Pentremites and the Archimedes, and Dr. Dale Owen has designated the group Pentremital limestones, from the abundance of those fossils. The oolitic stratum lies immediately beneath. No workable seam of coal has hitherto been found beneath the beds containing these fossils; Producte and Terebratule are abundant in them, and a small species of Calymene occurs. Dr. Owen regards these limestones as the equivalent of the mountain limestone of Europe. Iron ores occur at the junction of the limestone and coal measures, and galena and fluorspar have been found in the former.

The rocks which succeed to the Pentremital limestone are gray, yellow, and brown siliceous sandstones, soft and fine grained, sometimes argillaceous and free from mica, passing on the one hand into chert and limestone, and on the other into a rock presenting the appearance of Tripoli: interstratified with these are beds of limestone, occasionally oolitic. This group is not rich in organic remains ; Crinoidece, Polypiferce and Producte are most common. The middle and lower beds of this group are regarded by Dr. Owen as probable equivalents of the upper Ludlow rocks. 


\section{Dr. D. Dale Owen on the Geology of North America.}

We next in descending order arrive at a group of bituminous, aluminous shales and associate limestones, the lowest of which affords a valuable water cement. In the shale there are no fossils except a few slight impressions, apparently of seeds or seed-vessels. Where the shale is replaced by indurated clay, Dr. Troost has found Encrinites and Polypifera, and the "encrinital limestone" over the shale in Tennessee is rich in Crinoidea. Atrypa prisca, Orthis lunata vel orbicularis, Terebra sinuosa, Calymene bufo, and Asaphus macrurus occur in the water limestone. The shale, Dr. Owen considers, must probably be referred, as well as the water limestone, to the lower Ludlow, and may be regarded as the equivalent of the Helderberg group and Marcellus shales of the New York geologists. The encrinital limestone and the green fersuginous rock of Indiana may correspond with the Aymestry limestones.

Next in order is a group consisting almost wholly of compact limestones, lying in thick beds without any interstratified marls or shales. This rock is best developed towards the north-west, and in certain districts becomes a true magnesian limestone upwards of 500 feet in thickness. It closely approximates, both in lithological character, mineral contents, and even proximity to the coal measures, the "scar limestone" of England, and were it not for the organic remains might be mistaken for it. But, says Dr. Owen, the list of organic remains supplies proof hardly contestable, that the rocks in which they occur are equivalents of the Wenlock formation of Murchison. In the upper beds, Catenipora escharoides and Pentamerus hispidus are very abundant, with numerous other species recorded by the author in his memoir. In the lower hundred feet of this group fossils are scarce. Rich and important lead mines occur in it, the most valuable in the United States. The most characteristic fossil of the lead-bearing strata is the Coscinopora.

Next in order follow thin beds of shell limestone, alternating with marl and marlite, occupying a superficial area of about 10,000 square miles. The thickness of this group is greatest about the centre of the Ohio valley, where it is estimated at 1000 feet. In the north-west, at Prairie du Chien, it is but 100 feet, and near the Blue Mounds in Wisconsin, but a few feet in thickness; it abounds in organic remains. Among these are characteristic, Isotelus gigas, Triarthrus Bechii, several species of Conotubularia, and of Bellerophon and Maclurites; Isotelus planus, Lingula Lewisii, Orthis excentrica, Orthis alata, and Asterias antiqua. These fundamental rocks of the Ohio valley Dr. Owen considers the equivalents of the lower Silurian.

No inferlor rocks are visible in a north-west direction until the vicinity of the $W$ isconsin river, where the blue fossiliferous limestone rests conformably on a sandstone succeeded by a magnesian limestone, with few and imperfect fossils, so that its proper place is doubtful. The blue limestone in the south-east, beyond the Cumberland mountains, rests unconformably on the inferior stratified rocks of "Tennessee, which dip towards the granitic rocks. The author appends extensive lists of fossils.

An extensive series of rocks and fossils from the formations de- 


\section{Mr. Lyell on the Ridges, \&c. of the Canadian Lakes. 183}

scribed, with beautiful diagrams in illustration of the memoir, were presented to the Society by Dr. Dale Owen at this meeting.

2. On the Ridges, Elevated Beaches, Inland Cliffs and Boulder Formations of the Canadian Lakes and Valley of the St. Lawrence. By Charles Lyell, Esq., V.P.G.S., F.R.S.*

After adverting to his former paper on the Recession of the Falls of Niagara, and the observations which he made jointly with $\mathrm{Mr}$. Hall in the autumn of $1841+, \mathrm{Mr}$. Lyell gives an account of additional investigations made by him in June 1842; in the course of which he found a fluviatile deposit similar to that of Goat Island, on the right bank of the Niagara, nearly four miles lower down than the great Falls. The freshwater strata of sand and gravel here alluded to occur at the Whirlpool. They are horizontal, about forty feet thick, plentifully charged with shells of recent species, and are placed on the verge of the precipice overhanging the river. They are bounded on their inland side by a steep bank of boulder clay, which runs parallel to the course of the Niagara, marking the limit of the original channel of the river before the excavation of the great ravine. Another patch of sand, with freshwater shells, was detected on the opposite or western side of the river, where the Muddy Run flows in, about $1 \frac{\mathrm{I}}{2}$ mile above the Whirlpool. From the position of these strata it is inferred that the ancient bed of the river, somewhere below the Whirlpool, must have been 300 feet higher than the present bed, so as to form a barrier to that body of fresh water in which the various beds of fluviatile sand and gravel above-mentioned were accumulated. This barrier was removed when the cataract cut its way back to a point further south. The author also remarks, that the manner in which the freshwater beds of the Whirlpool and Goat Island come into immediate contact with the subjacent Silurian limestone, no drift intervening, shows that the original valley of the Niagara was shaped out of limestone as well as drift. Hence he concludes that the rocks in the rapids above the present Falls had suffered great denudation while yet the Falls were at or below the Whirlpool.

Mr. Lyell thinks that the form of the ledge of rock at the Devil's Hole, and of the precipice which there projects and faces down the river, proves the Falls to have been once at that point. An ancient gorge, filled with stratified drift, which breaks the continuity of the limestone on the left bank of the Niagara at the Whirlpool, was examined in detail by the author, and found to be connected with the valley of St. Davids, about three miles to the north-west. This ancient valley appears to have been about two miles broad at one extremity, where it reaches the great escarpment at St. Davids, and between 200 and 300 yards wide at the other end, or at the whirlpool. Its steep sides did not consist of single precipices, as in the ravine of Niagara, but of successive cliffs and ledges. After its de-

* Read Dec. 14, 1842, and January 4, 1843, 548].

† See Proceedings, vol. iii. p. 595 [or Phil. Mag. S. 3. vol. xxi. p. 


\section{Mr. Lyell on the Ridges, Elevated Beaches, \&c.}

nudation the valley appears to have been submerged and filled up with sand, gravel, and boulder clay, 300 feet thick.

A description is next given of certain modern deposits, containing freshwater shells, on the western borders of the Niagara, above the Falls, and in Grand Island, in order to show that the future recession of the Falls may expose patches of fluviatile sediment similar to those in and below Goat Island.

The author then passes to the general consideration of the boulder formation on the borders of Lakes Erie and Ontario, and in the valley of the St. Lawrence, as far down as Quebec. Marine shells were observed in this drift at Beauport, below Quebec, as first pointed out by Captain Bayfield, and also near the mouth of the Jacques Cartier river, and at Port Neuf and other places; also at Montreal, where they reach a height probably exceeding $\tilde{5} 00$ feet above the sea, the summit of Montreal mountain being 760 feet high, according to Bayfield's trigonometrical measurement, and the shells being supposed to be 240 feet below the summit. These shells, therefore, being more than 300 feet above Lake Ontario, we may presume that the sea in which the drift was formed extended far over the territory bordering that lake. The most southern point at which the author saw fossil shells belonging to the same group as those of Quebec was on the western and eastern shores of Lake Champlain, viz. at Port Kent and Burlington, in about lat. $44^{\circ} 30^{\prime}$. Here, and wherever elsewhere the contact of the drift is seen with hard subjacent rocks, these rocks are smoothed, and furrowed on the surface, in the same manner as beneath the drift in northern Europe. The species of shells occurring in the drift, to which Mr. Lyell has made some additions, are not numerous, and are all, save one, known to exist, but are inhabitants, for the most part, of seas in higher latitudes. Many of them are the same as those occurring fossil at Uddevalla and other places in Scandinavia, and they imply the former prevalence of a colder climate when the drift originated. At Beauport there are large and far-transported boulders, both in beds which overlie and underlie these marine shells.

The author next describes the ridges of sand and gravel surrounding the great lakes, which are regarded by many as upraised beaches. $\mathrm{He}$ examined, in company with Mr. Hall, the "Lake ridge," as it is called, on the southern shore of Lake Ontario, and other similar ridges north of Toronto, which were formerly explored by Mr. Roy*, and which preserve a general parallelism to each other and to the neighbouring coast. Some of these have been traced for more than 100 miles continuously. They vary in height from ten to seventy feet, are often very narrow at their summit, and from fifty to 200 yards broad at their base. Cross stratification is very commonly visible in the sand; they usually rest on clay of the boulder formation, and blocks of granite and other rocks from the north are occasionally lodged upon them. They are steeper on the side towards the lakes, and they usually have swamps and ponds on their inland side; they are higher for the most part and of larger dimensions

* See Proceedings, vol. ii. p. 537 [or Phil. Mag. S. 3. vol. xi. p. 201]. 
than modern beaches. Several ridges, east and west of Cleveland in Ohio, on the southern shore of Lake Erie, were ascertained to have precisely the same characters. Mr. Lyell compares them all to the osars in Sweden, and conceives that, like them, they are not simply beaches which have been entirely thrown up by the waves above water, but that many of them have had their foundation in banks or bars of sand, such as those observed by Capt. Grey running parallel to the west coast of Australia, lat. $24^{\circ} \mathrm{S}$., and by $\mathrm{Mr}$. Darwin off Bahia Blanca and Pernambuco in Brazil, and by $\mathrm{Mr}$. Whittlesey near Cleveland in Lake Erie. They are supposed to have been formed and upraised in succession, and to have become beaches as they emerged, and sometimes cliffs undermined by the waves. 'The transverse and oblique ramifications of some ridges are referred to the meeting of different currents and do not resemble simple beaches.

The base-lines of the ridges east and west of Cleveland, are not strictly horizontal according to Mr. Whittlesey, but inclined five feet and sometimes more in a mile. Those near Toronto are said by Mr. Roy to preserve the same exact level for great distances, but Mr. Lyell does not conceive that our data are as yet sufficiently precise to enable us to determine the levels within a few feet at points distant several hundred miles from each other. No fossil shells have been obtained from these ridges, and the author concludes that most of them were formed beneath the sea or on the margin of marine sounds. Some of the less elevated ridges, however, may be of lacustrine origin, and due to oscillations in the level of the land since the great lakes existed, for unequal movements, analogous to those observed in Scandinavia, may have uplifted freshwater strata above the barriers which divide Lake Michigan from the basin of the Mississippi, or Lake Erie from Ontario, or the waters of Ontario from the ocean. Considerable differences of level may have been produced in the ancient beds of these vast inland bodies of freshwater, while the modern deposit and the subjacent Silurian strata may to the eye appear perfectly horizontal.

The author then endeavours to trace the series of changes which have taken place in the region of Lakes Erie and Ontario, referring first to a period of emergence when lines of escarpment like that of Queenstown, and when valleys like that of St. Davids were excavated; secondly, to a period of submergence when those valleys and when the cavities of the present lake-basins were wholly or partially filled up with the marine boulder formation; and lastly, to the reemergence of the land, during which rise the ridges before alluded to were produced, and the boulder formation partially denuded. He also endeavours to show, how during this last upheaval the different lakes may have been formed in succession, and that a channel of the sea must first have occupied the original valley of the Niagara, which was gradually converted into an estuary and then a river. The great Falls, when they first displayed themselves near Queenstown, must have been of moderate height, and receded rapidly, because the limestone overlying the Niagara shale was of slight thickness at its northern termination. On the further retreat of the sea a second 


\section{Dr. Mantell and Mr. Redfield on American Fossils.}

fall would be established over lower beds of hard limestone and sandstone previously protected by the water; and finally, a third fall would be caused over the ledge of hard quartzose sandstone which rests on the soft red marl, seen at the base of the river-cliff at I.ewistown. These several falls would each recede further back than the other in proportion to the greater lapse of time during which the higher rocks were exposed before the successive emergence of the lower ones. Three falls of this kind are now seen descending a continuation of the same rocks on the Genesee River at Rochester. Their union, in the case of the Niagara into a single fall, may have been brought about in the manner suggested by $\mathrm{Mr}$. Hall*, by the increasing retardation of the highest cataract in proportion as the uppermost limestone thickened in its prolongation southwards, the lower falls meanwhile continuing to recede at an undiminished pace, having the same resistance to overcome as at first.

Mr. Lyell considers the time occupied by the recession of the Falls from the Whirlpool to be quite conjectural, but assigns a foot rather than a yard a year as a more probable estimate; thus he shows the Mastodon, found on the right bank near Goat Island, though associated with shells of recent species, to have claim to a very high antiquity, since it was buried in fluviatile sediment before the Falls had receded above the Whirlpool + .

3. Notice on a Suite of specimens of Ornithoidicnites, or foot-prints of Birds on the New Red Sundstone of Connecticut. By Gideon Algernon Mantell, LL.D., F.R.S $\$$.

These specimens were accompanied by a letter from Dr. James Deane of Greenfield, Massachusetts, the original discoverer of the Ornithoidicnites, of which more than thirty varieties had been found, bearing a striking resemblance to the foot-prints of birds. In this letter Dr. Deane gives an account of his discovery of the impressions eight or nine years ago, and which he then communicated to Professor Hitchcock. He remarks, that " the footsteps are invariably those of a biped, and occur on the upper surface of the stratum, while the cast or counter-impression is upon the lower. In some instances we may follow the progress of the animal over as many as ten euccessive steps." He has seen a course of steps twelve inches in length by eight in breadth, extending several rods. The intervening space was uniformly four feet. One impression of a foot was fourteen inches in length. The impressions are accompanied by those of rain-drops.

4. Extract of a Letter from W. C. Redfield, Esq., on newly discovered Ichthyolites in the New Red Sandstone of New Jersey. Communicated by Charles Lyell, Esq., V.P.G.S $\$$.

$\mathrm{Mr}$. Redfield has found two distinct fish-beds in the new red sandstone of New Jersey, both containing ichthyolites of the genus

* Boston Journ. of Nat. Hist., 1841.

+ [On the subject of Mr. Lyell's paper, as noticed by Mr. Murchison, see our preceding volume, pp. 548-550.-Eols.]

† Read Dec. 14, 1842. See also our preceding volume, p. 557 .

$\S$ Read Dec. 14, 1842. 


\section{Mr. Lyell on the Tertiary Strata of Martha's Vineyard. 187}

Palaoniscus. In the sandstone between the fish-beds he discovered an Ornithoidicnite, and observed numerous slabs exhibiting impressions of rain-drops and ripple-marks. The rain-marks appear as if the rain had been driven by a strong wind, and the direction of the impressions indicated that the wind blew from the west, a quarter from which violent squalls or thundergusts are still prevalent in these latitudes.

5. On the Tertiary Strata of the Island of Martha's Vineyard in Massachusetts. By Charles Lyell, Esq., V.P.G.S., \&c.*

The most northern limit to which the tertiary strata bordering the Atlantic have been traced in the United States is in Massachusetts in Martha's Vineyard, lat. $41^{\circ} 20^{\prime}$ north, an island about twenty miles in length from east to west, and about ten from north to south, and rising to the height of between 200 and 300 feet above the sea. The tertiary strata of this island are, for the most part, deeply buried beneath a mass of drift, in which lie huge erratic blocks of granite and other rocks which appear to have come from the north, probably from the mountains of New Hampshire. The tertiary strata consist of white and green sands, a conglomerate, white, blue, yellow, and blood-red clays and black layers of lignite, all inclined at a high angle to the north-east, and in some of their curves quite vertical. They are finely exposed near Chilmark on the southwest side of the island, and in the promontory of Gay Head at its south-western extremity, where there is a vertical section of more than 200 feet in height.

Attention was first called to this formation by Prof. Hitcheock in 1823, who appears to be the only American geologist who has examined them personally. He compared the beds at Gay Head to the plastic and London clays of Alum Bay in the Isle of Wight, to which, lithologically, they bear a striking resemblance, consisting in both cases of variously and brightly coloured clays and sands with lignite, all incoherent and highly inclined. Various opinions, however, have been put forth as to the relative age of the Martha's Vineyard strata, which were assigned by Prof. Hitchcock, at a time when the tertiary formations of the United States were less known, to the Eocene period, while Dr. Morton supposed them to be in part only tertiary, and that they rested on greensand of the cretaceous period.

The section at Gay Head is continuous for four-fifths of a mile, the beds dip to the north-east generally at an angle of from thirtyfive to fifty degrees, though in some places at seventy degrees. The clays predominate over the sands. In one place Mr. Lyell found a great fold in the beds, in which the same osseous conglomerate and associated beds of white sand, on the whole fifty feet thick; were so bent as to have twice a north-easterly and once a south-westerly dip. In the yellowish and dark brown clay near the uppermost part of the section at Gay Head, and in the greensand immediately resting upon it + , Mr. Lyell found the teeth of a shark, that of a seal, vertebræ of

* Read Feb. 1, 1843. See Mr. Murchison's notice of the contents of this paper, p. 551 of our preceding volume.

+ Nos. 5 and 6 of Prof. Hitchcock's section. 


\section{$188 \mathrm{Mr}$. Lyell on the Tertiary Strata of Martha's Vineyard.}

Cetacea, crustacean remains and casts of Tellina and Mya. These prevail at intervals through a thickness of nearly 100 feet, and are followed by beds of sand and clay with lignite. Mr. Lyell found no remains in the red clays. Many rolled bones were found in the osseous conglomerate.

In the section at Chilmark similar strata to those at Gay Head occur, but the general dip is south-west. Some of the folds, however, give anticlinal dips to the north-east as well as the south-west, and there are many irregularities, the beds being sometimes vertical and twisted in every direction. Several faults are seen and veins of ironsand, which intersect the strata like narrow dykes, as if there had been cracks filled from above. One bed of osseous conglomerate at Chilmark, four yards in thickness, is vertical, and its strike is well seen to be north $25^{\circ}$ east, so that the disturbances have evidently been so great that it would be difficult without more sections to determine positively the prevailing strike of these beds. The incumbent drift is very variable in thickness, and large erratics, from twenty to thirty feet in diameter, are seen resting on quartzose sand. The author saw no grounds for concluding that any cretaceous strata occur anywhere in the island, nor could he find any fossils which appeared to have been washed out of a cretaceous formation into the tertiary strata, as some have suggested.

Mr. Lyell proceeds to the consideration of the organic remains collected by himself in Martha's Vineyard.

Mammalia.-1. A tooth, identified by Prof. Owen as the canine tooth of a seal, of which the crown is fractured. It seems nearly allied to the modern Cystophora proboscidea.

2. A skull of a walrus, differing from the skulls of the existing species (Trichecus rosmarus, Linn.), with which it was compared by Prof. Owen, in having only six molars and two tusks, whereas those of the recent have four molars on each side, besides occasionally a rudimentary one. 'The front tusk is rounder than that of the recent walrus.

3. Vertebræ of Cetacea, some of which are referred by Prof. Owen to the Whalebone-whales, and others to the Bottle-nosed ( $H y$ peroodon).

Pisces.-Teeth of sharks resembling species from the Faluns of Touraine, viz. Carcharias megalodon, Oxyrhina xiphodon, O. hastulis, and Lamna cuspidata. With these were large teeth of two species of Carcharias, one resembling C. productus, a Maltese fossil. With the exception of the two last, Mr. Lyell found the same species in miocene strata near Evergreen, on the right bank of James River in Virginia.

Crustacea.-A species considered by Mr. Adam White as probably belonging to the genus Cyclograpsus, or the closely allied Sesarma of Say, and another, decidedly a Gegarcinus.

Mollusca.--1. Casts of a Tellina allied to $T$. biplicata, a miocene fossil, and of another near T. lusoria. 2. Cast of a Cytherea resembling C. Sayana, Conrad. 3. Three casts of a $M y a$, one of which bears a close resemblance to Mya truncata. 


\section{Mr. J. H. Cooper on Fossil Bones found in Georgia. 189}

Mr. Lyell concludes, from the various evidence here given, that the strata of Martha's Vineyard are miocene. The numerous remains of Cetacea of the genera Balena and Hyperoodon are adverse to the supposition of their being Eocene, while such fossils abound in the miocene beds of America. The other fossils all point to a similar conclusion.

6. Letter from J. Hamilton Cooper, Esq., to Charles Lyell, Esq., V.P.G.S., On Fossil bones found in digging the New Brunswick Canal in Georgia*.

Mr. Cooper prefaces his communication by a description of the country surrounding the locality in which the bones were found. The portion described is that part of the sea-coast of Georgia which lies between the Alatamaha and Turtle rivers in one direction, and the Atlantic Ocean and the head of tide water on the other. For twenty miles inland the land is low, averaging a height of from ten to twenty feet, and reaching, in some instances, forty feet, and consisting of swamps, salt-marshes, sandy land, and ciay loam. It then suddenly rises to the height of seventy feet, and runs back west at this elevation about twenty miles, at which point there is a similar elevation of between sixty and seventy feet. The whole of this district is a post-tertiary formation, and is composed of recent alluvium, and a well-characterized marine post-pliocene deposit. The recent alluvium is divided into inland-swamp, tide-swamp, and saltmarsh. The two last occupy a shallow basin having a depth of about twelve feet, the bottom and sides of which are the post-pliocene formation. This the author divides into three groups, in the last of which, constituting the elevated sand hills, no organic remains have been found; in the two former marine shells of existing species occur.

The fossil bones of the land mammalia discovered by Mr. Cooper, were found resting on the yellow sand and enveloped in the recent clay alluvium. Their unworn state and the grouping together of many bones of the same skeleton, render it highly probable that the carcasses of the animals falling or floating into a former lake or stream, sank to the sandy bottom, and were gradually covered to their present depth by the sedimentary deposits from the water. Among them were remains of the megatherium, Mastodon giganteum, mammoth, hippopotamus and horse. The fossil shells found in the postpliocene, were species at present existing on the neighbouring shores.

'The facts narrated by $\mathrm{Mr}$. Cooper lead to the following conclusions :- 1 st. That the post-pliocene formation extends further south than Maryland, to which it has hitherto been limited. 2nd. The coexistence of the megatherium with the mammoth, mastodon, horse, bison, and hippopotamus. 3rd, That the surface of the country has undergone no sudden or violent change since those animals inhabited it, which is proved by the absence of all traces of diluvial action in the enveloping alluvium or surrounding country. 4th. That whatever changes of temperature may have taken place since that time, fatal to the existence of those manmalia, the identity of the fossil

* Read Feb. 1, 1843. See p. 552 of our preceding volume. 
with the existing species of the marine shells of the coast shows that the temperature of the ocean at a period prior to the existence of the megatherium, the mastodon, and the hippopotamus was such as is congenial to the present marine testacea of Georgia.

7. On the Geological position of the Mastodon giganteum and associated fossil remains at Bigbone Lick, Kentucky, and other localities in the United States and Canada. By Charles Lyell, Esq., V.P.G.S*.

With a view to ascertain the relations of the soil in which the bones of the Mastodon are found, to the drift or boulder formation, whether any important geographical or geological changes had taken place since they were imbedded, and what species of shells are associated with them, Mr. Lyell visited a number of places where they had been obtained. In this paper he gives the result of his researches.

The most celebrated locality visited was Bigbone Lick, in the northern part of Kentucky, distant about 25 miles to the $\mathbf{S . W}$. of Cincinnati, situated on a small tributary of the river Ohio called Bigbone Creek, which winds for about 7 miles below the Lick before jaining the Ohio. A "Lick" is a place where saline springs break out, generally among marshes and bogs, to which deer, buffaloes, and other wild animals resort to drink the brackish water and lick the salt in summer. The country around Bigbone Lick, and for a considerable distance on both banks of the Ohio, above and below it, is composed of blue argillaceous limestone and marl, constituting one of the oldest members of the transition or Silurian system. The strata are nearly horizontal and form flat table-lands intersected by numerous valleys in which alluvial gravel and silt occur; but there is no covering of drift in this region. The drift is abundant in the northern parts of Ohio and Indiana, but disappears almost entirely before we reach the Ohio.

Until lately herds of buffaloes were in the habit of frequenting the springs, and the paths made by them are still to be seen. Numbers of these animals have been mired in the bogs, and horses and cows have perished in like manner. Along with their remains are found innumerable bones of Mastodon, Elephant, and other extinct quadrupeds, which must have visited these springs when the valley was in its prescnt geographical condition in almost every particular, and which must have been mired in them as existing quadrupeds are at present. The mastodon remains are most numerous and belong to individuals of all ages. The mud is very deep, black, and soft. In places it is seen to rest upon the limestone, and at some points it swells up to the height of several feet above the general level of the plain and of the river. It is occasionally covered by a deposit of yellow clay or loam, resembling the silt of the Ohio, which is from 10 to 20 feet thick, rising to that height above the creek and often terminating abruptly at its edges. This loam has all the appearance of having been deposited tranquilly on the surface of the morass and of having afterwards suffered denudation.

* Read Feb. 1, 1843. See p. 552 of our preceding volume. 


\section{Mastodon giganteum in the United States and Canada. 191}

The Mastodon and other quadrupeds have been mired before the de. position of the incumbent silt, for a considerable number of fossil bones have been found by digging through it. Accompanying the bones are freshwater and land shells, most of which have been identified by Mr, Anthony with species now existing in the same region,

Mr. Lyell observes that the surface of the bog is extremely uneven, and acoounts for it partly by the unequal distribution of the incumbent alluvium, which presses with a heavy weight on certein parts of the morase, from which other portions of the surface are entirely free. He also attributes it in part to the swelling of the bog where it is fyily saturated with water near the springs.

The author is of opinion that the fossil remains of Bigbone Lick are much more modern than the deposition of the drift, which is not present in this district. But although the date of the imbedding of these mammalian fossil remains is so extremely modern, considered geologieally, it is impossible to say how many thousand years may not have elapsed sinoe the Mastodon and other lost species became extinct. They have been found at the depth of several feet from the surface, but we have no data for estimating the rate at which the boggy ground has increased in height, nor do we know how often during floods its upper portion has been swept away.

Qhio.-The Ohio river immediately above and below Cincinnati is bounded on its right bank by two terraces consisting of sand, gravel and loam, the lower terrace consisting of beds supposed to be muoh newer than those of the upper. In the gravelly beds of the higher terruoe teeth both of the Mastodon and elephant have been met with. Mr. Lyell was assured that a boulder of gneiss, 12 feet in diameter, was found resting on the upper terrace, about 4 miles north of Cincinnati, and that some fragments of granite had been found in a similar situation at Cineinnati itself. These facts show that some large erratics have taken up their present position singe the older al. luvium of the Ohio valley was deposited, In travelling northwarde from Cincinnati towards Cleveland, Mr. Lyell found the northern drift commence in partial patches 25 miles from the former city and about 5 miles $N_{\text {. E }}$, of Lebanon, after which it eontinually increased in thickness as he proceeded towards Lake Erie.

New York-Niagara Falls.-In a former paper Mr. Lyell alluded to the position of the remains of Mastodon, 12 feet deep, in a freshwater formation on the right bank of the river Niagara at the Falls*. He remarks that if we had not been able to prove that the eataract had receded nearly four miles since the origin of the fluviatile strata in question, we should have been unable to assign any considerable duration of time as having intervened between the inhumation of the Mastodon in marl full of existing shells and the present period. The general covering of drift between Lakes Erie and Ontario is considered to be of much higher antiquity than the gravel containing the bones of the Mastodon at the Falls.

Rochester. - In the suburbs of this eity remains of the Mastadon

* [See Phil. Mag. B. 3. vol. xxi. p. 554.] 
giganteum were found associated with existing species of Mollusca in gravel and marl below peat.

Genesee.-Here remains of the Mastodon giganteum were found with existing shells in a small swamp in a cavity of the boulder formation, so that the animal must have sunk after the period of the drift when a shallow pond fed by springs was inhabited by the same species of freshwater mollusca as now live on the spot.

Albany and Greene Counties.-Mr. Lyell examined, in company with Mr. Hall, two swamps west of the Hudson River, where the remains of Mastodon occurred in both places at a depth of four or five feet, precisely in such situations as would yield shell marl, and peat, with remains of existing animals in Scotland. Cattle have recently been mired in these swamps.

According to Mr. Hall the greatest elevation at which Mastodon bones have been found in the United States is at the town of Hinsdale, situated on a tributary of the river Allegany in Cattaraugus county in the State of New York, where they occur at an elevation of 1500 feet above the level of the sea.

Maryland.-In the museum at Baltimore, Mr. Lyell was shown the grinder of a Mastodon, distinct from $M$. giganteum, and which had been recognised and labelled by $\mathrm{Mr}$. Charlesworth as $M$. longirostris, Kaup. It was found at the depth of 15 feet from the surface in a bed of marl near Greensburgh, in Carolina County, Maryland, and is considered by Mr. Lvell as a miocene fossil.

Atlantic border.-Between the Appalachian mountains and the Atlantic there is a wide extent of nearly horizontal tertiary strata, which at the base of the mountains are 500 feet and upwards in height, but decline in level nearer the ocean and at length give place to sandy plains and low islands skirting the coast, in which strata containing marine shells of recent species are met with, slightly elevated above the sea. Occasionally deposits formed in freshwater swamps occur, below the mean level of the Atlantic or overflowed at high tide. In this district Mr. Nuttall discovered, on the Neuse 15 miles below Newburn, in South Carolina, a large assemblage of mammalian bones, including those of the Mastodon giganteum, resting on a deposit containing marine shells of recent species. Mr. Conrad presented Mr. Lyell with the tooth of a horse covered with barnacles, from this locality. Professor Owen has examined it and could find no corresponding tooth of a recent species, but considers it as agreeing with the horse-tooth brought by Mr. Darwin from the north side of the Plata in Entre Rios in South America.

South Carolina.-Remains of the Mastodon were found in digging the Santee Canal, in a spot where large quadrupeds might now sink into the soft boggy ground.

Georgia.-Bones of the Mastodon and Megatherium occur in this district in swamps formed upon a marine sand containing shells of species now inhabiting the neighbouring sea*.

Mr. Lyell in conclusion offers the following observations :-

1. That the extinct animals of Bigbone Lick and those of the At-

- Antè, p. 189. 
lantic border in the Carolinas and in Georgia belong to the same group, the identical species of Mastodon and elephant being in both cases associated with the horse, and while we have the Mylodon and Megatherium in Georgia, the Megalonyx is stated by several authors to have been found at Bigbone Lick*.

2. On both sides of the Appalachian chain, the fossil shells, whether land or freshwater, accompanying the bones of Mastodons, agree with species of Mollusca now inhabiting the same regions.

3. Under similar circumstances Mr. Darwin found the Mastodon and horse in Entre Rios, near the Plata, and the Megatherium, Megalonyx and Mylodon, together with the horse, in Bahia Blanca in Patagonia; these South American remains being shown by their geological position to be of later date than certain marine Newer Pliocene, and Post-pliocene strata. Mr. Darwin also ascertained that some extinct animals of the same group are more modern in Patagonia than the drift with erratics.

4. The extinct quadrupeds before alluded to in the United States lived after the deposition of the northern drift, and consequently the coldness of climate which probably coincided in date with the transportation of the drift, was not as some pretend the cause of their extinction.

[* One of the conclusions to which the facts narrated by Mr. J. Hamilton Cooper, in his paper (antè, p. 189) on fossil bones found in Georgia, lead, is " the co-existence of the megatherium with the mammoth, mastorlon, horse, bison, and hippopotamus." Mr. Lyell states, above, the co-existence of the elephant (mammoth) and mastodon with the horse in the Bigbone Lick and in the Carolinas; and also, on the authority of Mr. Darwin, that of the mastodon and horse near the Plata, and of the megatherium, megalonyx, mylodon, and horse in Patagonia. A parallel case, to a certain extent, is afforded in the extreme north of the American continent, by the association in Eschscholtz Bay, of bones of the elephant (mammoth), bison (urus), musk-ox, deer, and horse; and if the writer of this note be correct in assigning to the megatherium a cervical vertebra, hitherto unappropriated, in the collection from Eschscholtz Bay, the parallelism of the case there presented with that occurring in Georgia will be very close; since in both localities we shall then have the co-existence of the megatherium, mammoth, horse, and bison. And further, the megatherium will then appear to have extended from the extreme south (Patagonia) to the extreme north (Eschscholtz Bay) of the New World; and to have been associated, throughout its range, with the horse, if not indeed with the other mammalia here enumerated. The former association, in America, of mammalia almost universally distributed, at some geological period, over Asia and Europe, but the living analogues

Phil. Mag. S. 3. Vol. 23. No. 151. Sept. 1843. 